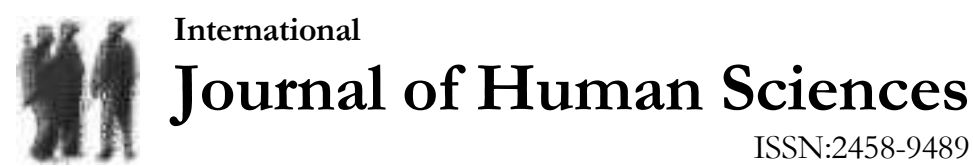

Volume 17 Issue 1 Year: 2020

\section{The study of the perceptions of internet and social media among adolescents and problematic use of internet}

\author{
Mercan Atalay ${ }^{1}$ \\ Göklem Tekdemir ${ }^{2}$
}

\begin{abstract}
The adolescents' perceptions of social media in relation with problematic internet use were examined in this study. The study group consisted of 209 students (113 girls, 96 boys), who were studying secondary schools in Istanbul. "Problematic Internet Usage Scale-Adolescent" and "Openended Questions Form on Internet and Social Networking Sites", were utilized by the researchers, and applied to adolescents in order to determine students' level of problematic use of the internet and their perceptions regarding social media. The analysis revealed that the adolescents who stated that they "needed" to use the internet had the highest level of problematic internet use. Significant age differences among adolescents with regard to meaning of internet pointed out how the internet played various purposes to individuals in various age groups. It has been determined that students in the 11-12 age group preferred to use the internet for "entertainment" purposes more than for other purposes. It was also found that the problematic use of the internet by these adolescents was associated with their opinions about their own academic achievements - specifically the participants who thought of themselves as "poor" students showed a higher use of the internet in correlation with high levels of negative consequences.
\end{abstract}

Keywords: Problematic use of the internet; adolescents, perceptions, internet, social media.

\section{Introduction}

The fastest development seen in this century are in the fields of information and communication technologies. In this context, internet has become an important part of our daily life. Internet offers users lots of useful information and tools thus its use is affecting everybody's lives in various ways (Beard and Wolf, 2001).

Distances have narrowed through e-mail and social media, communication with others has increased through the use of video conferences, global sharing of databases which provide information to and from libraries, world awareness increased due to better communications individuals are now aware of what is happening all around the world; all the while individuals' lives were made easier enabling the users to listen to music, watch movies, and play games, and now even shopping can be made effortlessly through the Internet (Esen and Siyez, 2011, Aydoğdu, 2003, Gönül, 2002).

\footnotetext{
1 Ph.D. Canditate, Istanbul University, Faculty of Letters, Department of Psychology, mercanpdr@gmail.com

${ }^{2}$ Assist. Prof, Istanbul University, Faculty of Letters, Department of Psychology, tekdemir@istanbul.edu.tr
} 
Atalay, M. \& Tekdemir, G. (2020). The study of perceptions of internet and social media among adolescents and problematic use of internet. Journal of Human Sciences, 17(1), 65-78. doi:10.14687/ihs.v17i1.5674

In addition to the conveniences provided by the internet, due to the increase in the duration and intensity of internet usage, new phenomena such as problematic internet usage and/or internet addiction were conceptualized recently. Problematic internet usage is defined as a multidimensional syndrome consisting of cognitive and behavioral symptoms leading to negative social, academic or occupational outcomes (Caplan, 2005). In another definition, the concept of problematic internet use is explained by the impairments experienced by individuals in family and work life due to internet usage. This problem is characterized by a compulsive use of the internet (Davis et al., 2009, Akt Ceyhan, 2010).

In this study, it was aimed to determine the relation between the rates of problematic internet usage, habits of internet use among adolescents residing in two different middle schools in Istanbul and to describe the ways these adolescents perceived their use of social media platforms on internet. Our goal was to contribute to the understanding of the problematic habits related to internet use by gathering qualitative data about what social networking meant for them, how they represented these platforms in relation to their academic and social life.

According to a study conducted by Türk Telekom in 2012, as the number of computers in homes increased in Turkey, the rate of internet connections provided has also increased. Today, thanks to the availability of smart phones, being at home for access to the internet has become unnecessary. As a result of a study conducted in the United States, adolescents between 12-17 years of age constituted the greatest percentage among users $-93 \%$ of all users (Lenhart, Purcell, Smith and Zickuh, 2010). In Turkey, however, the internet usage rate of adolescents in the 11-15 age group was determined as 65\% ((TÜİK, 2013).

For adolescents, it was found that the leading activity they preferred during their leisure time was the use of the internet (Aslan and Cansever, 2012). It was identified that the the internet was used by adolescents for various activities such as researching information, chatting, gaming, listening to music, watching movies, web-surfing, and social networking (Kayri and Günüç, 2010; Yüksel and Baytemir, 2010; Tarı Cömert and Kayıran, 2010; Yılmaz, Şahin, Haseski and Erol, 2014; Çelik, Çelen and Seferoğlu, 2014).

It was observed that as the duration of the internet use increased, the likelihood of developing addiction based on the negative consequences of internet use among adolescents had increased (Koff and Günüç, 2010; Üneri and Tanıdır, 2011). In these studies, a major gender effect was observed among these adolescents. Dependency and time spent online were determined to be greater among males compared to females in the same age group and they were more prone to use the internet (Tarı Cömert and Kayıran; 2010; Üneri and Tanıdır, 2011; Çelik et al., 2014; Yılmaz et al., 2014).

Reports show that the excessive use of the Internet had negative results on family life of individuals as well as personal relationships and in terms of labor productivity (Chou, Condron and Belland, 2005 cited in Üneri and Tanıdır, 2011). This problem was defined as internet addiction (Young, 1996; 2004; Griffiths, 1999). It is proven by Young (1998), that 58\% of students who used the internet excessively, developed negative studying habits and were found to have lower grades or failed their classes altogether.

Internet addiction problem in Turkey since this technology is used by relatively young people capable of using this technology more competently, is more prevalent among children and adolescents. The families have been resorting to addiction rehabilitation centers for their children's treatment (Arisoy, 2009). The studies conducted with adolescents in Turkey revealed different rates of Internet addiction. In their study, Üneri ve Tanidir (2011), found an internet addiction rate of 24.2\% among high school students while Seferoğlu and Yildız (2013) in their study of 5th and 6th grade students observed this rate to be at 4.8\%. In their study Ylmaz and his colleagues (2014), the rate of internet addiction among high school students was identified as $16.3 \%$. This difference might be explained by methodological differences or by the different definitions of internet dependency in these studies (Üneri and Tanıdır, 2011). 
Atalay, M. \& Tekdemir, G. (2020). The study of perceptions of internet and social media among adolescents and problematic use of internet. Journal of Human Sciences, 17(1), 65-78. doi:10.14687/ihs.v17i1.5674

According to Kurlk (2014, p.340) social media is one of the sources of the internet developing into a mass media tool. According to the author, social networking platforms like Facebook, Twitter, Linkedin resulted in an increase in the interest of internet usage.

According to the research performed by Lenhart and his colleagues $(2010, \mathrm{p} .17), 73 \%$ of American adolescents within the age group of 12-17 years of age are using social networking sites, and this figure has been determined to increase even more from 2006 to today. According to the same study, only $8 \%$ of these adolescents showed that they used the internet for other purposes than using Twitter and other social media sites. Moreover, the findings of Seferoğlu and Yildız (2013) revealed that adolescents in Turkey mostly used Twitter (23.7\%) (p.41). In the same study, it was observed that $74.4 \%$ of adolescents had a Facebook account and $46.7 \%$ of these adolescents logged into Facebook several times a day.

Studies conducted in Greece, Spain, Poland, Germany, Romania, the Netherlands and Iceland showed that the adolescents in the 14-17 age group were utilizing the internet in a negative way and were addicted primarily due to social media sites such as Facebook (Tsitsikama, Janiki, Schoenmakers, Tzavel et al., 2014: 532). According to Espinoza and Juvonen (2011), secondary school students read the comments in their very own profile page using social networks and that they spent the majority of their time in these social networks to comment and reply to the activities in their own profile pages.

A comprehensive study was carried out as a result of the combined efforts of the "Internet Board of the Ministry of Transport," with support of "Middle East Technical University (METU)" and the Head of "Information Technologies and Communications Authority Telecommunication" in Turkey. The aims of this study were to find how adolescents used the social media and their habits formed via use of the internet. The resulting report published in February 2011 indicated that out of the 9-16 age groups, 70\% used the internet once a day, and from that group $66 \%$ reported that they used the social networks once a day, and that on average they used 72 minutes in these social platforms online. The observed rates showed that the majority of the time children and adolescents spent online was for the purposes of social networking. Among these platforms, Facebook was the most used social media network with a 99\% usage rate. The report also showed that $60 \%$ of children stating that their time on these social networks had a negative impact on their studying time.

Based on all these reports, we see that social media has its benefits as well as its risks which necessitates to question and understand the meaning and representations of the social networking and the internet.

\section{Research questions}

This study focuses on investigating use and meanings attributed to the internet and social networking sites by the adolescents in the age group of $11-15$, the following research questions were formulated:

i. How do different variables such as gender, age, level of parents' education and their occupation, family's level of income, the starting age of using the internet, and purposes of using the internet impact adolescents' level of problematic use of internet?

ii. How do adolescents in the age group of 11-15 describe and evaluate the Internet and the social networking platforms?

iii. What is the relationship between the adolescents' evaluations and their level of problematic internet usage? 
Atalay, M. \& Tekdemir, G. (2020). The study of perceptions of internet and social media among adolescents and problematic use of internet. Journal of Human Sciences, 17(1), 65-78. doi:10.14687/jhs.v17i1.5674

\section{Method}

This research is a study aimed at revealing the problematic internet usage levels of adolescents and their opinions about the internet and social networking sites such as Facebook, Twitter and Whatsapp in relation to socio-demographic variables.

\section{Participants}

The study group consisted of 209 students including 113 (54.1\%) girls and 96 (45.9\%) boys, who were studying during 2014-2015 education year in two secondary schools in the districts of Ataköy and Şişli in Istanbul. These students were randomly selected. The socio-demographic characteristics of participants are presented in Table 1.

Table 1.

Socio-Demographic Characteristics of the Sample

\section{Socio-Demographic Characteristics}

Gender

$\begin{array}{lll}\text { Female } & 113 & 54.1 \\ \text { Male } & 96 & 45.9\end{array}$

Age

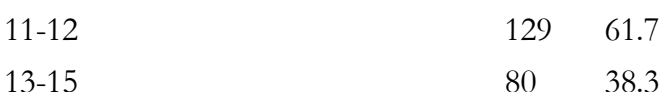

Mother's Education

$\begin{array}{lll}\text { Primary school graduate } & 24 & 11.5 \\ \text { Secondary school graduate } & 28 & 13.4 \\ \text { High school graduate } & 80 & 38.3 \\ \text { College } & \text { one } & 0.5 \\ \text { Graduated from a Universty } & 57 & 27.3 \\ \text { Master - PhD } & 54 & 1.9 \\ \text { Empty } & 15 & 7.2\end{array}$

Father's Education

Occupational Profession

$\begin{array}{lll}\text { Primary school graduate } & 13 & 6.2 \\ \text { Secondary school graduate } & 20 & 9.6 \\ \text { High school graduate } & 88 & 42.1 \\ \text { College } & \text { 2nd } & \text { one } \\ \text { Graduated from a Universty } & 70 & 33.5 \\ \text { Master - PhD } & 5 & 2.4 \\ \text { Empty } & 10 & 4.8\end{array}$

$\begin{array}{lll}\text { Housewife } & 117 & 56 \\ \text { Other } & 88 & 42.1 \\ \text { Left blank } & 4 & 1.9\end{array}$

Father's Job

$\begin{array}{lll}\text { Engineer } & 15 & 7.2 \\ \text { Textile } & 9 & 4.3 \\ \text { Self-employment } & 12 & 5.7\end{array}$


Atalay, M. \& Tekdemir, G. (2020). The study of perceptions of internet and social media among adolescents and problematic use of internet. Journal of Human Sciences, 17(1), 65-78. doi:10.14687/jhs.v17i1.5674

\begin{tabular}{llll}
\hline & Other & 197 & 79.9 \\
& Left blank & 6 & 2.9 \\
Monthly Total Family's Income & & & \\
& $0-1000 \mathrm{TL}$ & 10 & 4.8 \\
& $1001-2000 \mathrm{TL}$ & 30 & 14.4 \\
& $2001-3000 \mathrm{TL}$ & 37 & 17.7 \\
& $3001-4000 \mathrm{TL}$ & 28 & 13.9 \\
& $4001-5000 \mathrm{TL}$ & 17 & 8.1 \\
& $5000+\mathrm{TL}$ & 33 & 15.8 \\
& Left blank & 53 & 25.4 \\
\hline
\end{tabular}

Three measuring tools were used to collect the data: (i) Demographic Information Questionnaire, (ii) Open-ended Questions Form on Internet and Social Networking Sites and (iii) Problematic Internet Usage Scale-Adolescent Form.

\section{Instruments}

\section{Measures of Open-ended Questions Form on Internet and Social Networking Sites and Demographic Information Questionnaire}

These forms were developed by the researchers based on the results of previous studies. In the demographic information form, there were questions about the socio-demographic characteristics of the students. The Open-ended Questionnaire consisted of several questions about their habits of internet use and their opinions about the internet. In this questionnaire the participants' opinions and evaluations about Facebook, Twitter and Whatsapp were obtained by asking them to fill in 4 different sentence completions for the concept of internet and for each social networking platform (for example, 1- "I use the internet to .............." , 2- "The Internet means.......... for me ...", 3-"If internet did not exist............", 4- "Instead of the Internet ...............might have been invented").

Problematic Internet Usage Scale - Adolescent Form (PIKO-E)

In the present study, Problematic Internet Use Scale-Adolescents Form developed by Ceyhan and Ceyhan (2009) was used in order to determine the rates of problematic internet use in the sample group. The problematic internet use scale was first developed by Ceyhan, Ceyhan and Gurcan (2007) to measure the problematic internet use levels of university students. The scale was later adapted to adolescents. The 27 items of the PIKÖ-E are calibrated scores ranging from 1 to 5 (given a total score ranging from 27 to 137), with higher scores reflecting a greater tendency toward a problematic use of the internet indicating a risk of developing internet addiction. The overall internal consistency coefficient of the scale was .93 (Ceyhan ve Ceyhan, 2009). The factor analysis of this scale resulted in three sub-scales named as (i) "negative consequences of the internet", (ii) "overuse" and (iii) "social benefit / social comfort".

In this study, the Cronbach's alpha coefficient for the internal consistency of the entire scale was 0.92 and the correlation between the test scores for the items was found to be between .25 and .68 per the results from the scores obtained by the study group.

\section{Procedure}

To analyze how sociodemographic variables (age, gender, level of parents' education and their occupation, family's level of income), the starting age of using the internet, and reported purposes of using the internet impacted the adolescents' scores of problematic internet use several t-tests and one-way analysis of variance (ANOVA) were conducted.

In the qualitative analysis phase of the study, thematic content analysis was used to analyze the answers provided by the participants in sentence completions. The data was coded in the form 
Atalay, M. \& Tekdemir, G. (2020). The study of perceptions of internet and social media among adolescents and problematic use of internet. Journal of Human Sciences, 17(1), 65-78. doi:10.14687/ihs.v17i1.5674

of explicit coding by two graduate students trained by the second author of the study and these students were not aware of the purpose of the study. The codes and the resulting themes were revised by a second researcher, and the final version of the themes were created in accordance with the objectives of the present research.

Median value for the participants' scores on Problematic Internet Use Scale was used to create two groups: The group of problematic internet use consisted of participants with scores higher than the median value and the group of no problematic internet use consisted of participants with scores lower than the median value on this scale. Chi square analysis was conducted to determine whether the frequencies of the responses provided in the sentence completions differed significantly among these two groups. For all quantitative analysis SPSS 21 was used.

\section{Results}

The t-test for independent groups was conducted to determine whether the sample's scores on the Problematic Internet Use Scale differed significantly in terms of age and gender. The analysis revealed no significant differences among age and gender groups.

For the other socio-demographic variables such as level of income, parents' level of education and their occupation one-way analysis of variance (ANOVA) tests were conducted to determine whether the participants' scores of problematic internet use differed significantly. No significant differences were found.

However, the participants' scores of problematic internet usage were found to differ significantly among their perceived student profiles based on the results of ANOVA test conducted $[\mathrm{F}(3 ; 172)=3,847 ; \mathrm{p}<.05]$.

In other words, problematic internet use varied significantly, depending on which student profile the adolescents attributed to themselves (see Table 2).

Table 2.

Analysis of variance for adolescents' Problematic Internet Use Total Scores in terms of perceived student profiles

\begin{tabular}{llllll}
\hline Source & $d f$ & $S S$ & $M S$ & $F$ & $p$ \\
\hline Between groups & 3 & 5191.34 & 1730.44 & 3.84 & .01 \\
Within groups & 169 & 76022.69 & 449.83 & & \\
Total & 172 & 81214.04 & & & \\
\hline
\end{tabular}

$\mathrm{p}<.05$

The Tukey HSD test was carried out to find out where the differences within the groups came from. According to the Tukey HSD test, the level of problematic internet use differed significantly among groups of the adolescents who perceived themselves as "poor" students $(\mathrm{X}=$ 76.83), "average" students $(X=61.45)$, "above-average" students $(X=51.12)$, and "outstanding" students $(X=61)$. Self-proclaimed "poor students" had a higher score of problematic internet use compared to the participants who claimed to be average, above average, and outstanding students. There were also significant differences in terms of problematic internet use between specific groups based on perceived student profiles, especially those between "poor" and "above average" student profiles, "average" and "above-average" student profiles, "outstanding" and "above-average" profiles, and between "average" and "poor" student profiles.

It was determined that the participants' scores on problematic internet use scale, its subscales and their attributions about the internet did not differ significantly.

However, the difference between the groups based on the participants' perceived profiles was found to be statistically significant $[\mathrm{F}(3 ; 172)=5,982 \mathrm{p}<.05]$. In other words, the scores of the problematic internet use scale in the context of adverse outcomes varied significantly depending on the students' perceived profile. 
Atalay, M. \& Tekdemir, G. (2020). The study of perceptions of internet and social media among adolescents and problematic use of internet. Journal of Human Sciences, 17(1), 65-78. doi:10.14687/ihs.v17i1.5674

When we looked at whether the participants' scores on sub-scales of PIKO-E differed significantly among groups based on perceived student profiles, ANOVA test revealed no significant group differences based on the participants' scores on subscales of overuse and social benefit. However, the scores of from the sub-scale of adverse outcomes were found to differ significantly among groups of different perceived student profiles as revealed by ANOVA test [F $(3 ; 172)=5,982 \mathrm{p}<.05]$ (see Table 3).

Table 3.

ANOVA results for adverse outcome sub-scale scores according to perceived student profiles

\begin{tabular}{llllll}
\hline Source & $d f$ & SS & $M S$ & $F$ & $p$ \\
\hline & & & & & .00 \\
Between groups & 3 & 2787,44 & 919,14 & 5.98 & 1 \\
Within groups & 169 & 26248,25 & 155,31 & & \\
Total & 172 & 29035,7 & & & \\
\hline
\end{tabular}

$\mathrm{p}<.05$

The Tukey HSD test was done to find out where the differences within the groups came from. According to the results of the Tukey HSD, it was found that there was a significant difference between the self-perceived poor student $(X=43)$, average $(X=27,95)$, above-average $(X=21,88)$ and outstanding $(X=28,64)$ profiles. Self-proclaimed "poor" students' scores on adverse outcomes sub-scale were higher than those of average, above-average, and outstanding student profile groups.

The responses of the adolescents given to sentence-completion questions asked about internet, Facebook, Twitter and WhatsApp were analyzed by thematic content analysis. The themes based on the thematic content analysis of the adolescents' opinions on the Internet and the frequency of themes according to age groups are given in Table 4.

Table 4.

The frequency and distribution of themes according to age groups

\begin{tabular}{|c|c|c|c|c|}
\hline Questions: & * Frequency & Age Group & & Examples of Expressions \\
\hline 1 What comas to your mind when you hear the word internet & & Agess 11-12 & Ages 13-15 & \\
\hline \multirow[t]{2}{*}{ The purpose of use of the internet } & t & 47 & 48 & Games, entertainment, and course income \\
\hline & ๓ & 49,5 & 50.5 & \\
\hline \multirow[t]{2}{*}{ Vacilities presented by the internet } & $f$ & so & 26 & Facebook, games, YouTube, Instagram \\
\hline & * & 69,4 & 30,6 & \\
\hline \multicolumn{5}{|l|}{ 2. Uses/meaning of the internet } \\
\hline \multirow[t]{2}{*}{ Entertainment } & t & 118 & 62 & For online games \\
\hline & $\%$ & 65,6 & 34,4 & \\
\hline \multirow[t]{2}{*}{ Requirement } & i & 5 & 9 & Studyine, shopping \\
\hline & \% & 35,7 & 64,3 & \\
\hline \multicolumn{5}{|l|}{ 3. What does the inturnet mean to you } \\
\hline \multirow[t]{2}{*}{ Source/Entertainment } & $\mathrm{t}$ & 37 & 27 & Recreation and Repetition of Course \\
\hline & $\$ 6$ & 57,8 & 42,2 & \\
\hline \multirow[t]{2}{*}{ Not necessary } & i & 34 & 20 & Necessity/life \\
\hline & * & 56,7 & 43,3 & \\
\hline \multicolumn{5}{|l|}{ 4. What would there be if the internet wasn't around } \\
\hline \multirow{3}{*}{ Fallure to meet need } & & & & Thad difticulty in some issues. \\
\hline & $\mathrm{t}$ & 35 & 16 & difficult and boring life \\
\hline & $\%$ & 68,6 & 31,4 & \\
\hline \multirow[t]{2}{*}{ Lass of a sourte } & i & 39 & 25 & I could not learn the things I didr't know \\
\hline & 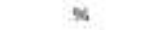 & 68,8 & 31,3 & \\
\hline \multicolumn{5}{|l|}{ 5. What would be invented if the internet never existed } \\
\hline \multirow{2}{*}{ Something conceptually close to the internet } & f & 25 & 20 & Nothing, unique \\
\hline & $\%$ & 55,6 & 44,4 & \\
\hline \multirow[t]{2}{*}{ Another indepedent technology } & + & 32 & 6 & Hoiosram, lightspeed \\
\hline & $\%$ & 84,2 & 15.8 & \\
\hline
\end{tabular}

The adolescents defined the internet as a "resource of information- source of entertainment" and a "need" from their own perspectives. When asked why they used the internet, $65 \%$ of adolescents in the 11-12 age group stated that they used it for "entertainment" purposes. However, the percentage of adolescents expressing that they used the internet as a "need" was very small. 
Atalay, M. \& Tekdemir, G. (2020). The study of perceptions of internet and social media among adolescents and problematic use of internet. Journal of Human Sciences, 17(1), 65-78. doi:10.14687/jhs.v17i1.5674

The frequency of themes generated based on the thematic content analysis of adolescents' views on social networking sites such as are presented in Table 5.

Table 5.

The frequency and distribution of themes associated with Facebook, Twitter and Whats App according to age groups

\begin{tabular}{|c|c|c|c|c|}
\hline Questions & \% Frequency & Age Group & & Examples of Expressions \\
\hline 1. I use Facebook for...... & & Ages 11.12 & Ages 13-15 & \\
\hline \multirow[t]{2}{*}{ To form communication } & $f$ & 59 & 38 & Talk to my friends \\
\hline & $\%$ & 60,8 & 39,2 & \\
\hline Multi-purpose use & $\%$ & 64,1 & 35,9 & \\
\hline \multicolumn{5}{|l|}{ 2. Facebook for me...means } \\
\hline Communication & $f$ & 46 & 24 & Communicate \\
\hline \multirow[t]{2}{*}{ It is insignificant } & $f$ & 18 & 15 & It doesn't matter \\
\hline & $\%$ & 54,5 & 45,5 & \\
\hline \multicolumn{5}{|c|}{ 3. If Facebook did not exist...then what would happen } \\
\hline \multirow[t]{2}{*}{ Communication would be distrupted } & $f$ & 37 & 22 & I wouldn't be able to talk to my friends \\
\hline & $\%$ & 62,7 & 37,3 & \\
\hline Nothing would have happened & $f$ & 29 & 16 & Nothing would have changed \\
\hline \multirow[t]{2}{*}{ Nothing unique } & $f$ & 26 & 11 & Nothing would please \\
\hline & $\%$ & 70,3 & 29,7 & \\
\hline \multicolumn{5}{|l|}{ 5. Twitter to me....means } \\
\hline \multirow{2}{*}{ Nothing } & $f$ & 29 & 14 & It is insignificant \\
\hline & $\%$ & 67,4 & 32,6 & \\
\hline \multirow[t]{2}{*}{ A need } & $f$ & 7 & 8 & Compulsory requirement \\
\hline & $\%$ & 46,7 & 53,3 & \\
\hline \multicolumn{5}{|l|}{ 6. If twitter did not exists...what then would } \\
\hline \multirow[t]{2}{*}{ Nothing unique } & $f$ & 36 & 21 & Nothing would have changed \\
\hline & $\%$ & 63,2 & 36,8 & \\
\hline 8. Whatsapp for me...means & & & & \\
\hline I communication tool & $f$ & 48 & 29 & The greatest communication tool \\
\hline & $\%$ & 62,3 & 37,7 & \\
\hline I don't use it & $f$ & 23 & 17 & I don't use it \\
\hline & $\%$ & 57,5 & 42,5 & \\
\hline 9. If Whatsappp did not exist... what wo & & & & \\
\hline 1 don't use it & $f$ & 19 & 17 & I don't use it \\
\hline & $\%$ & 52,8 & 47,2 & \\
\hline Another indepedent technology & t & 23 & 10 & Constantly renewable newspapers \\
\hline & $\%$ & 69,7 & 30,3 & \\
\hline 10. Instead of Whatsapp, what would be & & & & \\
\hline I don't use it & t & 20 & 19 & I don't use it \\
\hline & $\%$ & 51,3 & 48,7 & \\
\hline There are no other alternatives & $f$ & 28 & 5 & Nothing \\
\hline & $\%$ & 84,8 & 15,2 & \\
\hline
\end{tabular}

In this study, Facebook and Whatsapp were evaluated as "communication tools". Twitter was found to be the least preferred social network platform among the adolescents in this study. The adolescents evaluated Twitter as "insignificant". 
Atalay, M. \& Tekdemir, G. (2020). The study of perceptions of internet and social media among adolescents and problematic use of internet. Journal of Human Sciences, 17(1), 65-78. doi:10.14687/ihs.v17i1.5674

In order to determine how the adolescents' levels of problematic internet use related to their opinions and evaluations about the internet and 3 social networking sites, firstly two groups based on sample's scores on PIKO-E were created. These two groups were created based on the median value of the total scores of PIKO-E. The median value was 54,5. So based on that the participants whose scores were above this value was included in the group with problematic internet use, and those with lower scores were included in the group with no problematic internet use.

Firstly, it was determined that the percentage of answers given to the question "what comes to your mind when you hear the word internet?" differed significantly between the groups with and without problematic internet use $\left[\chi^{2}=9,1 ; \mathrm{p}<.05\right]$. Adolescents who used the internet extensively emphasize the possibilities provided by the internet, while the adolescents in the group that did not use the internet in this way emphasized the purposes of using the internet.

Another meaningful differentiation among these groups was also found in the themes determined for the question "What internet means for me ..." [ $\left.\chi^{2}=14,5 ; \mathrm{p}<.05\right]$. According to this result, the internet was defined as a necessary tool of entertainment and communication by the group with problematic internet use at a higher level than the group with no problematic use. The participants of the group with non-problematic internet use reported internet to be a resource used for the lessons and assignments.

The other significant difference between these groups was found in the context of the themes determined for the question "what could have been invented instead of the internet" $\left[\chi^{2}=\right.$ $17,03 ; \mathrm{p}<.05]$. Adolescents who used the Internet excessively emphasized that the internet was "unique", while the adolescents in the group of non-problematic use emphasized that "another technology independent" from the internet could be developed. There were, however, no significant group differences in terms of the themes generated for two other questions regarding the internet.

As a result of the same sentence completions about Facebook, it was found that only the themes obtained for the question of "if Facebook did not exist ..." differed significantly between the groups $\left[\chi^{2}=23,03 ; \mathrm{p}<.01\right]$. When we looked at the distribution of these themes among the groups, it was found that the problematic internet users emphasized negative personal consequences resulting from lack of Facebook, while the other group emphasized the disruption of communication.

The themes generated from the answers for the same questions about Twitter and WhatsApp revealed no significant group differences.

\section{Discussion and Conclusions}

In this study, it was aimed to determine the relation between rates of problematic internet usage, habits of internet use and the ways of making sense of social networking platforms among adolescents aged 11-15 years from two different middle schools in Istanbul.

According to the results of the analysis, it was determined that adolescents did not differ in terms of level of problematic internet use according to age, gender as well as other sociodemographic variables such as level of family income, parents' levels of education and occupations and age of first use of internet).

The observation of lack of gender differences in our study is consistent with other studies measuring relationships between gender and problematic internet use (Hall and Parsons, 2001; Leung, 2004; Ceyhan, 2010). On the other hand, there are studies showing that the problematic internet usage changed among gender groups. The levels of pathological use of the internet, for example were found to be greater among males than in females(Morahan-Martin and Schumacher, 2000; Bayraktar and Gün, 2007; Kenny and Donaldson, 1991; Tahiroglu, Celik and Uzel, 2008; Wohlgemuth and Betz, 1991; Zorbaz and Dost, 2014; Cicioğlu, 2014). A reason for not observing an effect of gender might be due to the fact that a measure of problematic use indicating a possible 
Atalay, M. \& Tekdemir, G. (2020). The study of perceptions of internet and social media among adolescents and problematic use of internet. Journal of Human Sciences, 17(1), 65-78. doi:10.14687/jhs.v17i1.5674

development of pathological behavior was used in this study rather than a measure of pathological use.

In the present study, it was found that there was a meaningful relationship between adolescents' problematic internet usage and their self-perceived academic achivement levels determined by their choices among categories of profiles ranging from poor to outstanding. Adolescents who viewed themselves as "poor" students in terms of academic performance had a higher level of problematic internet use than those adoloscents who perceived themselves as "average," "above-average," and "outstanding" students. This result seems to be consistent with the results of other studies that have shown that excessive internet use does affect performance in school (Ni et al., 2009; Gencer et al., 2011). Thus, the adolescents themselves might be attributing their lower levels of academic performance in relation to their habits of internet use and that they are aware of the adverse effects of excessive internet use.

Secondly, the adolescents' perceptions and opinions in relation to internet and social networking sites were examined. Their anwers about the internet converged on themes of "internet usage purposes" and the possibilities offered by the internet. They defined the internet as a "source of entertainment" and "need" from their own perspectives. When asked why they used the Internet, they reported to use it for "entertainment". In this study, Facebook and Whatsapp were seen as "communication tool"s by the adolescents in our study. Twitter was found to be the least preferred social media platform.

In the current research, when you look at the perceptions of adolescents regarding the internet and social networking sites, the adolescents reported to use the internet mostly for "playing games, entertainment and resource for lessons", followed by for accessing social networking platforms such as YouTube, Facebook, and Instagram. While they expressed they viewed Facebook and Whatsapp as "communication tools".

Our findings regarding the internet and social networking sites are very similar to Günlü and Ceyhan's results (2017). The adolescents in their study also reported that "the internet enabled them to communicate" and that they used the internet "to entertain themselves".

Using the internet as a means of entertainment and communication was also found in several other studies (Shaw and Gant, 2002; Ceyhan and Ceyhan, 2007; Choi, 2001; Kim and Davis, 2009; Li and Chung, 2006; Morahan-Martin and Schumacher , 2000; Oguz, Zayim, Özel and Saka, 2008; Weitzman, 2000). The other reasons for using the internet in our study were playing games and searching for information as found in previous studies(Becker, 2000; Nalwa and Anand, 2003; Tsai and Lin, 2003; Akkoyunlu and Orhan, 2004; Yang et al., 2005; Gündoğdu, 2006; Bayraktar and Gün, 2007; Karaca, 2007; Yang and Tung, 2007; Makas, 2008; Tahiroğlu et al., 2008; Tripodaki et al., 2008; Canbaz, 2009; Korkeila et al, 2009; Tekinarslan and Gürer, 2009; Günaydın et al., 2010).

Finally, the relationships between levels of problematic internet use and how the internet and social networking sites were perceived and evaluated were explored. Two groups; one with problematic internet use and the other with non-problematic internet use were created. When we looked at whether the adolescents' opinions were related to being in either group, we determined that the percentage of answers given to the question "what comes to mind when you think of the internet" differed significantly between the group with and without problematic internet use. Adolescents who used the internet excessively emphasized the possibilities provided by the internet, while adolescents in the non-problematic use group emphasized their purposes for using the internet.

These groups' answers to the sentence "the internet means ..........for me" were also found to be significantly different. The internet was described as a necessary tools of entertainment and communication tool at a higher rate by the group with problematic internet use. The other group, however, describet it as a resource for the lessons and assignments. Similar to our results, Ceyhan and her colleagues (2009) in their study with university students found that problematic 
Atalay, M. \& Tekdemir, G. (2020). The study of perceptions of internet and social media among adolescents and problematic use of internet. Journal of Human Sciences, 17(1), 65-78. doi:10.14687/jhs.v17i1.5674

internet users utilized the internet for communication and entertainment as well as information acquisition purposes while non-problematic users used it as a resource of information.

Significant differences between the groups were also found in the context of the themes given in the question "what could have been invented instead of the Internet". Adolescents who used the Internet excessively emphasized that the internet was "unique", while the adolescents in the other group reported that "another technology independent" from the internet could be developed. This finding seems to be in line with the definition of addiction where the object addicted to becomes incomparable and irreplaceable for the addict since the scale we used in this study predicts that adolescents with higher scores are likely to develop an internet addiction in the future.

As a result of asking the same questions about Facebook, only the themes obtained from the answers given for the question "if Facebook did not exist........." were found to differ significantly between the groups. When we looked at the distribution of these themes among the groups, it was found that the problematic internet users emphasized its negative consequences for them as individuals, while the other group emphasized the disruption of communication. This finding is also in line with a framework of an addiction, where the object of addiction seems to be internalized as a part of the self by the adolescents with excessive use of the internet. The role of the internet and Facebook in this case seems to be critical for these adolescents.

It was found that the themes created as a result of the same questions about Twitter and WhatsApp did not significantly differentiate between the groups using the problem internet and those who did not. Our findings regarding Twitter use were not consistent with Seferoğlu and Yildız (2013) who found that adolescents in Turkey mostly used Twitter. We argue that this result might be due to the fact that the questions used in this study were not formulated to ask whether the individual used Twitter or had an active account.

There are several limitations of this study that we must note. The first one is that asking many questions with similar contents about the internet and social media resulted in some of the questions to be left blank since teenagers tend to get bored easily. Secondly, since the data was collected only from two similar schools in Istanbul the results cannot be generalized.

As a result, when research findings are taken into consideration, some important conclusions can be drawn for practitioners and researchers. It is necessary for the adolescents to be informed and made aware of the problems arising from problematic internet usage, and its consequences often leading to academic failure. It is important to provide guidance and create support groups who can identify and evaluate groups who are at risk. It was found that the adolescents who had problematic internet usage were more prone to say they used the internet for "entertainment" purposes. Therefore, it is necessary to provide them with more social activities in their school environment and give them further assistance in terms of learning in online settings and using other educational software to support their academic achievements.

In future studies, we believe that conducting focus group interviews with adolescents might provide more in-depth information about what the internet symbolizes for them and what they mean when they talk about "entertainment" and "necessity" in this context so that we can better see it from their perspective and plan relevant interventions.

\section{References}

Arısoy, Ö. (2009). İnternet Bağımlılı̆̆ ve Tedavisi/Internet Addiction and Its Treatment. Psikiyatride Guncel Yaklasimlar, 1(1), 55.

Aslan, N., \& Cansever, B. A. (2012). Ergenlerin boş zaman değerlendirme algısı. Hacettepe Üniversitesi Ë̈itim Fakültesi Dergisi, 42(42).

Aydoğdu, C. (2003). Televizyon ve bilgisayarn (18-24 yaş) gençler väzerindeki psikolojize etkileri: Hendek örneği (Yüksek Lisans Tezi , Sakarya Üniversitesi Sosyal Bilimler Enstitu "̈sü). Sakarya. https://tez.yok.gov.tr/UlusalTezMerkezi/ adresinden edinilmiştir. 
Atalay, M. \& Tekdemir, G. (2020). The study of perceptions of internet and social media among adolescents and problematic use of internet. Journal of Human Sciences, 17(1), 65-78. doi:10.14687/jhs.v17i1.5674

Bayraktar F, Gün Z (2007) Incidence and correlates of internet usage among adolescents in North Cyprus. Cyberpsychology \& Behavior 10:191 -197.

Bayraktar, F., \& Gün, Z. (2006). Incidence and correlates of Internet usage among adolescents in North Cyprus. CyberPsychology \& Behavior, 10(2), 191-197.

Beard, K. W., \& Wolf, E. M. (2001). Modification in the proposed diagnostic criteria for Internet addiction. Cyberpsychology \& Behavior, 4(3), 377-383.

Becker, P. J., Byers, B., \& Jipson, A. (2000). The contentious American debate: the first amendment and Internet-based hate speech. International Review of Law, Computers \& Technology, 14(1), 33-41.

Canbaz, S., Sunter, A. T., Peksen, Y., \& Canbaz, M. A. (2009). Prevalence of the pathological internet use in a sample of Turkish school adolescents. Iranian Journal of Public Health, 38(4), 64-71.

Caplan, S. E. (2005). A social skill account of problematic Internet use. Journal of communication, 55(4), 721-736.

Ceyhan, E. (2010). Problemli internet kullanım düzeyi üzerinde kimlik statüsünün, internet kullanım amacının ve cinsiyetin yordayıcılığı. Kuram ve Uygulamada Ë̆itim Bilimleri, 10(3), 1323-1355.

Ceyhan, A. A., \& Ceyhan, E. (2009). Ergenlerde problemli internet kullanım ölçeği (PİKÖ-E) geliştirme çalışmaları. X. Ulusal Psikolojik Danışma ve Rebberlik Kongresi sözlü bildiri, Adana.

Ceyhan, E., Ceyhan, A. A., \& Gürcan, A. (2007). The validity and reliability of the Problematic Internet Usage Scale. Kuram Ve Uygulamada Egitim Bilimleri, 7(1), 411.

Choi, Y. J. (2001). Investigating Koreans' internet use patterns and motivations, and exploring vulnerability of internet dependency.

Cicioğlu, M. (2014). Öğrencilerin problemli internet kullanmı ve siber zorbahle davramıslarna ilişkein görüşleri (Yüksek Lisans Tezi. Abant İzzet Baysal Üniversitesi). Eğitim Bilimleri Enstitüsü, Bolu. https://tez.yok.gov.tr/UlusalTezMerkezi/ adresinden edinilmiştir.

Cömert, I. T., \& Kayıran, S. M. (2010). Çocuk ve ergenlerde internet kullanımı. Çocuk Dergisi, 10(4), 166-170.

C,elen, F. K., C,elik, A., \& Seferoglu, S. S. (2011). Çocuklarn internet kullanumlar ve onlar bekleyen,evrimiçi riskeler. XIII. Akademik Bilişim Konferansı (AB11)'da sunular bildiri Inönü Universitesi, Malatya, 2, 4.

Esen, E., \& Siyez, D. M. (2011). Ergenlerde internet bağımlılı̆̆ını yordayan psiko-sosyal değişkenlerin incelenmesi. Türk Psikolojik Danışma ve Rehberlik Dergisi, 4,127-138.

Espinoza, G., \& Juvonen, J. (2011). The pervasiveness, connectedness, and intrusiveness of social network site use among young adolescents. Cyberpsychology, Behavior, and Social Networking, 14(12), 705-709.

Gencer, C., Altuğ, M., \& Ersöz, F. (2011). Ortaöğretim öğrencilerinin hayatında bilgisayarın yeri. Bilişim Teknolojileri Dergisi, 4(1).

Gönül, A. S. (2002) Patolojik internet kullanımı (İnternet bağımlılı̆̆ı / kötüye kullanımı). Yeni Symposium, 40 (3),105-110.

Griffiths, M. (1999). Internet addiction: fact or fiction? The Psychologist, 12 (5), 246-250.

Gündoğdu, D. (2006). Illkëğretim ögrencilerinin internet kullanm düzeyleri ve amaçlar (Yüksek Lisans Tezi, Fırat Üniversitesi, Sosyal Bilimler Enstitüsü, Eğitim Bilimleri, Elazı̆̆g). https://tez.yok.gov.tr/UlusalTezMerkezi/ adresinden edinilmiştir.

Günlü, A., \& Ceyhan, A. A. (2017). Investigating adolescents' behaviors on the internet and problematic internet usage. Addicta: The Turkish Journal on Addictions, 4, 75-117.

Günüç, S., \& Kayri, M. (2010). Türkiye'de internet bağımlılık profili ve internet bağımlılık ölçeğinin geliştirilmesi: Geçerlik-güvenirlik çalışması. Hacettepe Üniversitesi Ë̆itim Fakültesi Dergisi, 39, 220-232. 
Atalay, M. \& Tekdemir, G. (2020). The study of perceptions of internet and social media among adolescents and problematic use of internet. Journal of Human Sciences, 17(1), 65-78. doi:10.14687/jhs.v17i1.5674

Hall, A. S., \& Parsons, J. (2001). Internet addiction: College student case study using best practices in cognitive behavior therapy. Journal of mental health counseling, 23(4), 312-327.

Karaca, M. (2007). Sosyolojik bir olgu olarak internet genc ,liği: Elazı̆g örnegi (Doktora tezi, Firat Universitesi, Sosyal Bilimler Enstitüsü, Elazıg). https://tez.yok.gov.tr/UlusalTezMerkezi/ adresinden edinilmiştir.

Kırık, A. M. (2014). Aile ve çocuk ilişkisinde internetin yeri: Nitel bir araştırma. Ĕgitim ve Öğretim Araştırmaları Dergisi, 3 (1), 337-347.

Kenny, M. E., \& Donaldson, G. A. (1991). Contributions of parental attachment and family structure to the social and psychological functioning of first-year college students. Journal of Counseling Psychology, 38(4), 479.

Kim, H. K., \& Davis, K. E. (2009). Toward a comprehensive theory of problematic Internet use: Evaluating the role of self-esteem, anxiety, flow, and the self-rated importance of Internet activities. Computers in Human Behavior, 25(2), 490-500.

Lenhart, A., Purcell, K., Smith, A., \& Zickuhr, K. (2010). Social Media \& Mobile Internet Use among Teens and Young Adults. Millennials. Pew Internet \& American Life Project. http://www.pewinternet.org/files/oldmedia/Files/Reports/2010/PIP Social Media and Young Adults Report Final with $t$ oplines.pdf adresinden edinilmiştir.

Leung, L. (2004). Net-generation attributes and seductive properties of the internet as predictors of online activities and internet addiction. CyberPsychology \& Behavior, 7(3), 333-348.

Li, S. M., \& Chung, T. M. (2006). Internet function and Internet addictive behavior. Computers in Human Behavior, 22(6), 1067-1071.

Makas, Y. (2008). Lise öğrenimi gören gençlerin internet kullanımının psikososyal durum ile ilişkisi (Yüksek Lisans Teri, Beykent Üniversitesi, Sosyal Bilimler Enstitüsü). https://tez.yok.gov.tr/UlusalTezMerkezi//adresinden edinilmiştir.

Morahan-Martin, J., \& Schumacher, P. (2000). Incidence and correlates of pathological Internet use among college students. Computers in buman behavior, 16(1), 13-29.

Nalwa, K., \& Anand, A. P. (2003). Internet addiction in students: A cause of concern. Cyberpsychology \& behavior, 6(6), 653-656.

Ni, X., Yan, H., Chen, S., \& Liu, Z. (2009). Factors influencing internet addiction in a sample of freshmen university students in China. Cyberpsychology \& Behavior, 12(3), 327-330.

Ŏguz, B., Zayim, N., Özel, D., \& Saka, O. (2008). Tip öğrencilerinin internette bilişsel durumları. Akademik Bilişim, 30, 447-453.

Orhan, F., \& Akkoyunlu, B. (2004). İlköğretim öğrencilerinin internet kullanımları üzerine bir çalışma. Hacettepe Üniversitesi Ë̆itim Fakültesi Dergisi, 26(26), 107-116.

Seferoğlu, S. S., \& Yıldız, H. (2013). Dijital çağın çocukları: İlköğretim öğrencilerinin Facebook kullanımları ve internet bağımlılıkları üzerine bir araştırma. İletişim ve Diplomasi, 2, 31-48.

Shaw, L. H., \& Gant, L. M. (2002). In defense of the Internet: The relationship between Internet communication and depression, loneliness, self-esteem, and perceived social support. Cyberpsychology \& behavior, 5(2), 157-171.

Tahiroglu, A. Y., Celik, G. G., Uzel, M., Ozcan, N., \& Avci, A. (2008). Internet use among Turkish adolescents. CyberPsychology \& Behavior, 11(5), 537-543.

Tekinarslan, E., \& Gürer, M. D. (2009, May). Problemli internet kullanimi: eğitim fakültesi öğrencileri üzerinde çok yönlü bir inceleme problematic internet use: A multidimensional investigation on faculty of education students. In Proceedings Of 9 Th International Educational Technology Conference.

Tripodaki, E., Kormas, G. \& Konstantoulaki, E. (2008). Internet Use And Abuse In An Adolescent Population In Athens: Associations With Psychological Profile And Lifestyle Of Users. Official Joumal of the American Academy of Pediatrics, 121, 89-90. 
Atalay, M. \& Tekdemir, G. (2020). The study of perceptions of internet and social media among adolescents and problematic use of internet. Journal of Human Sciences, 17(1), 65-78. doi:10.14687/ihs.v17i1.5674

Tsai, C. C., \& Lin, S. S. (2003). Internet addiction of adolescents in Taiwan: An interview study. CyberPsychology \& Behavior, 6(6), 649-652.

Tsitsika, A., Janikian, M., Schoenmakers, T. M., Tzavela, E. C., Olafsson, K., Wójcik, S., ... \& Richardson, C. (2014). Internet addictive behavior in adolescence: a cross-sectional study in seven European countries. Cyberpsychology, Behavior, and Social Networking, 17(8), 528-535.

Türkiye İstatistik Kurumu (2013). Istatistiklerle Gençlik. http://www.tuik.gov.tr/PreHaberBultenleri. doi:13509 10.10.2013. tarihinde elde edilmiştir.

Üneri, Ö. Ş., \& Tanıdır, C. (2011). Evaluation of internet addiction in a group of high school students: a cross-sectional study. Düşünen Adam: The Journal of Psychiatry and Neurological Sciences, 24(4), 265-272.

Weitzman, E. A. (2000). Software and qualitative research. In N. Denzin and Y. Lincoln (Eds.) Handbook OfQualitative Research, 2nd Ed (pp. 803-820). Thousand Oaks: Sage.

Wohlgemuth, E., \& Betz, N. E. (1991). Gender as a moderator of the relationships of stress and social support to physical health in college students. Journal of Counseling Psychology, 38(3), 367-374.

Yang, S. C., Tung, C. J., (2007). Comparison of internet addicts and non-addicts in Taiwanese high school. Computers in Human Behavior, 23, 79-96.

Yang, C. K., Choe, B. M., Baity, M., Lee, J. H., \& Cho, J. S. (2005). SCL-90-R and 16PF profiles of senior high school students with excessive internet use. The Canadian Journal of Psychiatry, 50(7), 407-414.

Yılmaz, E., Şahin, Y. L., Haseski, H. İ., \& Erol, O. (2014). Lise öğrencilerinin internet bağımlılık düzeylerinin çeşitli değişkenlere göre incelenmesi: Balıkesir ili örneği. Ĕgitim Bilimleri Araştrrmalar Dergisi-Journal of Educational Sciences Research, 4(1), 133-144.

Young, K. S. (1998). Internet addiction: The emergence of a new clinical disorder. Cyberpsychology \& Behavior, 1(3), 237-244.

Yüksel, G., \& Baytemir, K. (2010). İlköğretim öğrencilerinin internet kullanım amaçları ile alg1ladıklar1 sosyal destek düzeylerinin incelenmesi. Türk Ë̆̈itim Bilimleri dergisi, 8(1), 1-20.

Zorbaz, O., \& Dost, M. T. (2014). Lise Öğrencilerinin Problemli Internet Kullanımının Cinsiyet, Sosyal Kayg1 Ve Akran Ilişkileri Açısından Incelenmesi. Hacettepe Üniversitesi Ĕ̈̌itim Fakültesi Dergisi, 29(1), 298-310. 